\title{
Borders, Kinship Disruption, and Collapsed Immobility: A Pendula of All My Relations
}

\author{
Keri Cheechoo \\ University of Ottawa \\ kchee096@uottawa.ca \\ Patrick Cheechoo, Artist \\ Constance Lake First Nation
}

\begin{abstract}
Words are like arrows...

Through poetic inquiry and art, this co-authored submission will include an inter/textual representation of Indigenous Métissage which will ask readers to 'explore' the lived experiences of colonialist displacement that has (re)framed kinship disruption through a lens that includes collapsed immobility. By engaging both ethical relationality and collapsed immobility (a response to a threat or strategies), the authors will navigate 'the self' through a lens that will speak to the (de)lineation and/or (non)existence of governmentally enforced borders present on ancestral territories. Leaning into ancestral aptitude, the authors will make space for All Our Relations to simultaneously step forward by reaching back to "come home" (McLeod, 2007, p. 67).
\end{abstract}




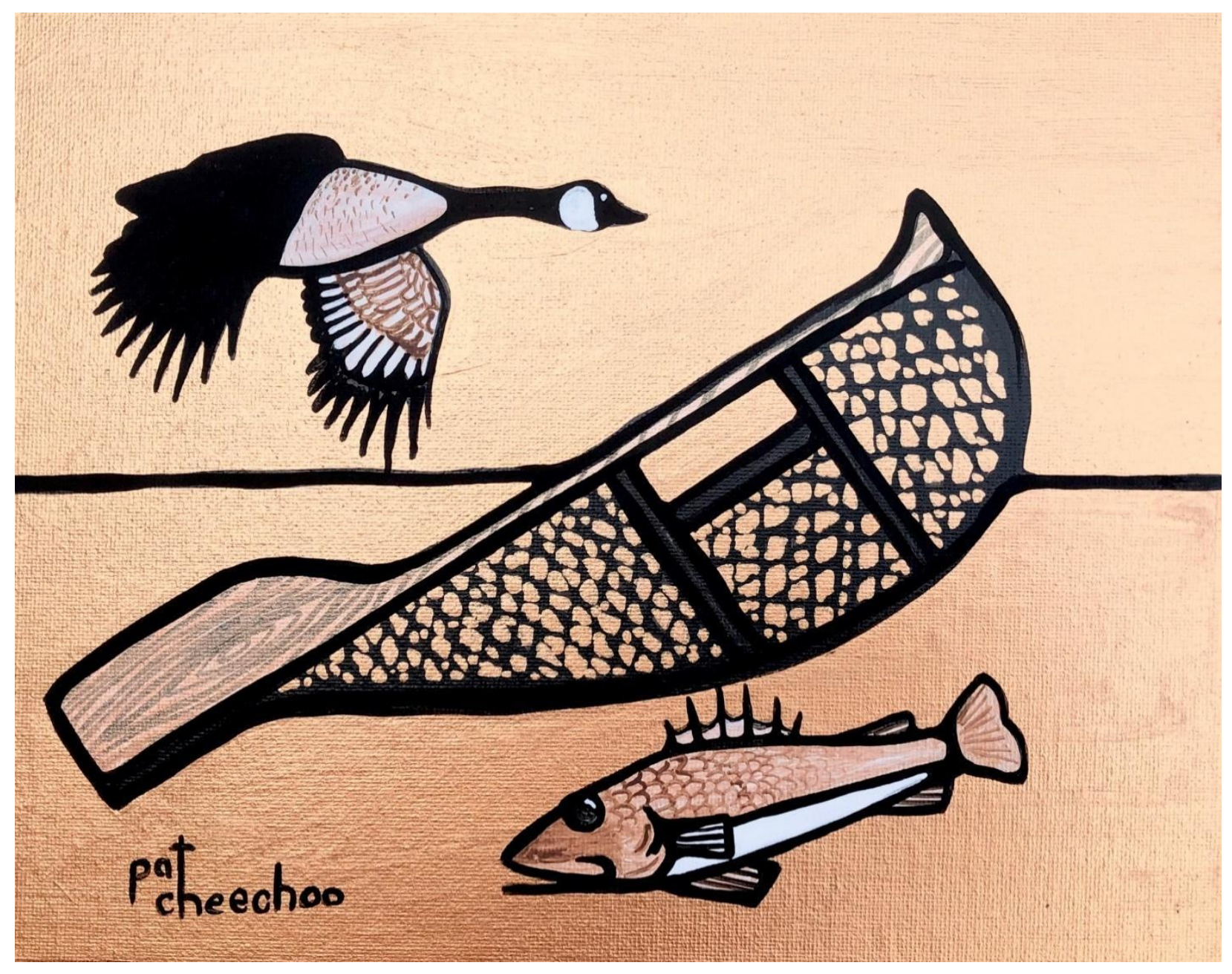

Title: “Journeys"

Artist: Patrick Cheechoo

Medium: Acrylic on Canvas Board

Size: $\quad 8 " \times 10 "$ 


$$
\begin{aligned}
& \text { (Im)Mobility } \\
& \text { I am } \\
& \text { a } \mathrm{p} \text { a } \mathrm{r} \mathrm{t} \\
& \text { first generation } \\
& \text { in my family } \\
& \text { that does not } \\
& \text { solely } \\
& \text { depend on the land } \\
& \text { survival | sustenance } \\
& \text { my parents } \\
& \text { spent } \\
& \text { childhoods } \\
& \text { hunting | fishing | trapping | harvesting } \\
& \text { plants and medicines, food } \\
& \text { security } \\
& \text { my ancestors } \\
& \text { traditional territories } \\
& \text { these territories } \\
& \text { supersede } \\
& \text { colonial boundaries } \\
& \text { in place today } \\
& \text { there are } \\
& \text { still } \\
& \text { supersede } \\
& \text { trapline } \\
& \text { boundaries }
\end{aligned}
$$




\author{
the \\ system \\ reduced \\ expansive regions \\ travelled by families \\ migrations \\ nisgaa \\ "canada" goose \\ the tributary \\ travels \\ of fish \\ my family would travel
}

\author{
a life of \\ mobility \\ and \\ adaptiveness \\ grandparents \\ travelled \\ the shores of James Bay \\ and into history \\ physical | metaphysical \\ (re) imagine (d) \\ ancestral \\ migration
}

(Keri Cheechoo, 2020) 
Indigenous worldview predicates an acceptance that active interconnectivity with past, present and future is ongoing. Accordingly, an Indigenous worldview conflicts with Canadian historical narratives because it disrupts long-held notions of ownership and settlement. Drawing on the work of Donald (2009), it is contended that Canada's creation story "continues to haunt our contemporary Canadian society by defining the terms according to which Aboriginal peoples and Canadians speak to each other about history, memory, place, and the land" (p. 40). And thus, using the "pedagogy of the fort", Donald (2009) explains that the binary of inside and outside comes into play. Those that are inside are considered safe, good, and industrious. Those on the outside are considered otherwise, and "outsiders must be either incorporated, or excluded, in order for development to occur in the desired ways" (p. 44).

To bridge these spaces, Donald suggests entering an ethical space that encompasses entities that are "Aboriginal and Canadian" (p. 44). Donald (2009) describes Indigenous Métissage as a "curriculum sensibility" that involves "purposeful juxtaposition" to "re-read and reframe historical understanding in ways that cause readers to question their own assumptions and prejudices as limited and limiting [...]" (p. 5). The concept of "purposeful juxtaposition" has been enacted to engage ethical relationality in the poem entitled (Im)Mobility.

By drawing on ethical relationality and Indigenous Métissage, this co-authored submission includes an inter/textual representation of Indigenous Métissage through poetic inquiry and art. We ask you to 'travel' the image and poem, recognize that lived experiences of colonialist displacement has (re)framed kinship, generated disruption through a lens that includes collapsed immobility (a response to a threat or strategies).

By engaging both ethical relationality and collapsed immobility, Cheechoo and Cheechoo have navigated 'the self' through a lens that speaks to the (de)lineation and/or (non)existence of governmentally enforced borders present on ancestral territories. By leaning into ancestral aptitude, we make space for All Our Relations to simultaneously step forward by reaching back to "come home" (McLeod, 2007, p. 67). Meegwetch. 


\section{References}

Cheechoo, K. (2020). (Im)Mobility. Crafted for Borders, Kinship Disruption, and Collapsed Immobility: A Pendula of All My Relations.

Cheechoo, P. (2020). Journeys. Crafted for Borders, Kinship Disruption, and Collapsed Immobility: A Pendula of All My Relations.

Donald, D. (2009). Forts, curriculum, and Indigenous Métissage: Imagining decolonization of Aboriginal-Canadian relations in educational contexts. First Nations Perspectives, 2(1), 1-24.

McLeod, N. (2007). Cree narrative memory: From treaties to contemporary times. Saskatoon, SK: Purich Pub. 